\title{
Challenges facing procurement professionals in developing economies: Unlocking value through professional international purchasing
}

\begin{abstract}
Authors:
Marian Tukuta ${ }^{1}$

Fanny Saruchera ${ }^{2}$

Affiliations:

${ }^{1}$ Department of Supply

Chain Management, School

of Entrepreneurship and

Business Sciences, Chinhoyi

University of Technology,

Zimbabwe

${ }^{2}$ Department of Consumer

Science, School of

Entrepreneurship and

Business Sciences, Chinhoyi

University of Technology,

Zimbabwe
\end{abstract}

Correspondence to:

Fanny Saruchera

Email:

sarucheraf@yahoo.com

Postal address:

Private Bag 7794, Chinhoyi,

Zimbabwe

Dates:

Received: 27 July 2014

Accepted: 27 Feb. 2015

Published: 30 Apr. 2015

How to cite this article: Tukuta, M. \& Saruchera, F., 2015, 'Challenges facing procurement professionals in developing economies: Unlocking value through professional international purchasing', Journal of Transport and Supply Chain Management 9(1), Art. \#152, 9 pages. http://dx.doi. org/10.4102/jtscm.v9i1.152

\section{Copyright:}

(C) 2015. The Authors. Licensee: AOSIS

OpenJournals. This work is licensed under the Creative Commons Attribution License.

Read online:
Background: Until recently, procurement was seen as a necessity only. In fact, in many developing economies the profession is still being treated as a 'back-office' function. However, not much has been done to explore and address challenges facing procurement professionals in developing economies.

Objectives: The purpose of this article was to examine the critical role played by the procurement function in business and to reveal the challenges faced by procurement professionals in developing economies as well as to suggest solutions to these challenges.

Method: A sequential literary analysis was used, complemented by cross-country qualitative data gathered from one hundred diverse procurement practitioners from Botswana, Namibia and Zimbabwe. These were primarily participants in a series of procurement workshops run by the researchers from January to June 2014.

Results: Findings suggested that limited recognition, increasing unethical behaviour, poor supplier service delivery, poor regulatory environment, varying supplier standards and poor corporate governance are the main challenges faced by the procurement profession in these countries.

Conclusion: The study's findings imply that there is limited understanding regarding the role procurement plays in both government and non-government institutions in developing economies. The article suggests solutions which procurement professionals and organisations can implement in order to unlock the potential value in the procurement function.

\section{Introduction}

The procurement discipline has come of age. Written on a red clay tablet found in Syria, the earliest procurement order back dates to between 2400 and 2800 BC (Thai 2001). The order was for ‘ 50 jars of fragrant smooth oil for 600 small weights in grain' (Coe 1989:87). Other evidence of historical procurement includes the development of the silk trade between China and a Greek colony in 800 BC (Page 1980). However, there were no professional procurement officials; goods and services needed by government were supplied by commissioners or commissaries, who received a commission on what they bought for the militia or other administrative units (Huston 1966; Thai 2001).

Although substantial improvements in the area have been made in the past three decades - for example, in the form of the centralised procurement systems (Page 1980), just-in-time (JIT) and total quality management (TQM) programmes (Mehra \& Inman 2004) - this was mostly in developed economies. In various developing economies, procurement - mostly public procurement - has not been viewed as having a strategic impact in the management of public resources. It has been mostly considered a process-oriented, 'back-office' support function often implemented by nonprofessional staff of buying agencies (Mehra \& Inman 2004:710). Little effort was made to ensure that the policies, rules and institutional framework governing the procurement system were maintained in a manner that ensured that especially public funds were used in the most efficient and economical way and that the system delivered the best value for money (Hunja 2003:1).

However, things have changed:

Until recently, procurement was a necessity, but seldom celebrated. [...] But times have changed; nowadays procurement functions within organisations are playing a critical role in the success of firms in ways that old-fashioned purchasing managers could never have thought of. (Gocke 2008:1)

Procurement has thus become an integral part of organisational performance and it is drawing increased attention from top to lower management levels. Despite shrinking budgets, 
procurement professionals are responsible for spending a huge proportion of companies' revenue or of the national budget (Anthon, Bogetoft \& Thorsen 2007; Levaggi 1999). Based on this development, organisational profitability, industry and country competitiveness as well as the organisation's responsiveness to customers' needs all now depend on how procurement professionals are effectively carrying out their responsibilities. Therefore ensuring high levels of professionalism in the discipline would help to eliminate most potential problems arising from international purchasing practices.

The movement of goods to all corners of the world is not an easy task and is prone to a myriad of problems and hurdles. These can be eliminated through experience, networking, strategic alliances, research, innovation and benchmarking. Against this background, the purpose of this article is to survey the role played by procurement professionals in the modern, dynamic business environment, and the strategic implications of procurement. Through interactions with practicing procurement staff at different levels, the study documents the diverse challenges facing the procurement function from a developing economy's perspective (with particular reference to Botswana, Namibia and Zimbabwe), in a bid to establish ways to unlock value through professional procurement regionally and internationally.

\section{Research methodology}

Given the insufficiency of original research related to procurement issues in developing economies, and the exploratory nature of this study, a sequential process of combining the existing procurement literature with realworld practices was adopted. More specifically, the method combined theoretical formulation with practice-oriented empirical validation (Mehra \& Inman 2004). Supported by literature (e.g. Meredith \& Samson 2001; Stuart et al. 2002), this research method is useful especially in developing wellgrounded theory and is helpful in explaining how and why events have occurred (Yin 1994).

The study involved reviewing existing literature on procurement and its role in modern-day business, which was then confirmed through a series of three procurement 'workshops' entitled 'Unlocking value through professional procurement', presented by the authors in Harare (Zimbabwe),
Gaborone (Botswana) and Windhoek (Namibia) from January to June 2014. Discussions at these workshops generated a host of challenges faced by procurement practitioners, which were then documented together with a prescription of academically informed solutions to these challenges.

The participants in the study ranged from top manufacturing executives of large multinational corporations and stateowned corporations to the lowest order taker of the smallest firm (Table 1), as the study involved input from a diverse range of group discussions. Panel discussions were held during the workshops, taking an approach almost similar to focus group discussions, where the workshop presenters acted like 'moderators'. Questions were posed to the different panels and follow-up questions were posed to the participants to probe for more responses. These participants were experienced in dealing with procurement activities over a period ranging from 1 to over 15 years in diverse business settings. Participating members were from diverse backgrounds and had varying qualifications, from certificates to Master's degrees in related disciplines.

Based on the diverse backgrounds of 100 active participants, the authors trusted that the participants were adequately competent to provide credible feedback on the challenges faced in the procurement field, as well as to assist in reflecting on the way forward. Workshop delegates were informed that outputs from the workshops would be compiled into a write-up for publication, thus written consent was obtained from the participants. Qualitative data were gathered, organised into thematic areas, analysed and blended with existing literature. Issues raised in the sessions in the three countries were almost similar - a clear indication that developing economies are facing almost similar challenges in the procurement profession. Stateowned enterprises had limited representation in all three countries yet these are the very same institutions that are facing many challenges compared to the private sector, which was fairly well represented.

\section{Literature review and theoretical framework}

The study was underpinned by supply chain management (SCM) theory. The theory highlights the growing need and importance of procurement professionals, as the

TABLE 1: Characteristics of the respondents.

\begin{tabular}{|c|c|c|c|c|c|c|c|c|c|c|}
\hline \multirow[t]{2}{*}{ Industrial sector } & \multirow{2}{*}{$\begin{array}{c}\text { Top } \\
\text { executives }\end{array}$} & \multicolumn{3}{|c|}{ Botswana } & \multicolumn{3}{|c|}{ Namibia } & \multicolumn{3}{|c|}{ Zimbabwe } \\
\hline & & $\begin{array}{l}\text { Middle-level } \\
\text { practitioners }\end{array}$ & $\begin{array}{l}\text { Lower-level } \\
\text { practitioners, } \\
\text { e.g. order } \\
\text { takers }\end{array}$ & $\begin{array}{c}\text { Top } \\
\text { executives }\end{array}$ & $\begin{array}{l}\text { Middle-level } \\
\text { practitioners }\end{array}$ & $\begin{array}{l}\text { Lower-level } \\
\text { practitioners, } \\
\text { e.g. order } \\
\text { takers }\end{array}$ & $\begin{array}{c}\text { Top } \\
\text { executives }\end{array}$ & $\begin{array}{l}\text { Middle-level } \\
\text { practitioners }\end{array}$ & $\begin{array}{l}\text { Lower-level } \\
\text { practitioners, } \\
\text { e.g. order } \\
\text { takers }\end{array}$ & Totals \\
\hline SMES & 2 & 8 & 4 & 0 & 6 & 3 & 6 & 6 & 5 & 40 \\
\hline $\begin{array}{l}\text { High-growth } \\
\text { oriented firms } \dagger\end{array}$ & 1 & 4 & 3 & 2 & 2 & 2 & 5 & 3 & 4 & 26 \\
\hline $\begin{array}{l}\text { State-owned } \\
\text { enterprises }\end{array}$ & 0 & 5 & 2 & 1 & 6 & 4 & 5 & 6 & 5 & 34 \\
\hline Totals & - & 30 & - & - & 26 & - & - & 44 & - & 100 \\
\hline
\end{tabular}

SMEs, small to medium enterprises.

$\dagger$, Firms seeking growth in order to have significant scale because of the impact on job creation they have, for instance Debswana (Botswana); Bidvest, Namibia Breweries (Namibia); Delta Beverages, Econet (Zimbabwe). The definition also includes participants from various multinational companies that took part in the workshops. 
scope of international purchasing is changing as a result of globalisation. Hines (2004) defines SCM as supply chain strategies requiring total systems views of the linkages in the chain that work together efficiently to create customer satisfaction. Supply chain management is broad in scope and considers the effect of functions other than procurement on business processes spanning multiple companies (Lambert \& Pohlen 2001). It is the integration of key business processes from the end-user right through to the original suppliers that provided the product(s), service(s) as well as the essential information that add value for customers and other stakeholders (Mentzer et al. 2001). It is therefore imperative that costs be lowered across the chain by driving out unnecessary costs and focusing on adding value (Al-Mudimigh, Zairi \& Ahmed 2004; Walters 2012).

Procurement professionals can use SCM to address problems in distribution network configurations, distribution strategies, trade-offs in logistics activities, information as well as cashflow transactions or payments (Schiele \& McCue 2006). SCM entails supply chain activity implementation, together with the management and coordination of order sourcing and processing, and movement of materials, information and finances through the supply chain (Modi \& Mabert 2010). As noted by Edler and Georghiou (2007), the rationale of SCM is to advance confidence or trust and improve collaboration amongst supply chain partners. As a result of globalisation, the proliferation of multinational companies worldwide and the increasing need for business partnerships, organisations are increasingly finding it necessary to rely on valuable supply networks to compete as a global and networked economy. There is therefore a demand for experienced procurement professionals who possess all the skills and technical expertise needed in international purchasing(Arora 2014). This highlights the role of procurement professionals as key members of the supply chain; hence the need for small to medium enterprises (SMEs), high-growth oriented firms and public corporations to upgrade their operations to augment effective procurement.

\section{The procurement function and its role in business}

According to McCue, Buffington and Howell (2007), procurement involves purchasing, renting, leasing or otherwise acquiring any supplies and services. It includes all functions that pertain to the process of acquisition, selection and solicitation of supply sources, preparation and award of contracts and all stages of supplier contract administration. It can be viewed as the combined functions of purchasing, inventory control, transportation, receiving, inspection, store keeping, and salvage and disposal operations (Hanks, Davies \& Perera 2008). Traditionally, and as confirmed by the respondents, the purchasing function has been associated with supplier sourcing, selecting the most suitable suppliers who adhere to the needs and requirements of the buyer, negotiating for contracts and appropriate payment methods, arranging for less costly means of transporting goods from the country of importation, and reporting to the procurement board on all transactions incurred during the purchasing contract and all other contracts entered into by the buyer (Hypo Group Alpe-Adria 2010).

The procurement function (purchasing) is considered a vital pillar in most manufacturing firms as it is responsible for over $60 \%$ of the firm's total expenditure through organisational inputs (Perry 2009:85). Findings in this study indicate that procurement professionals play a pivotal role in the success of a firm by performing in line with departmental goals. However, in order to achieve success these departmental goals should not conflict with the overall objectives of the organisation.

\section{The changing role played by procurement professionals}

In recent years, however, managing procurement activities have taken on a different meaning from that of earlier decades, as evidenced by numerous articles published on the subject of SCM (Brown, Bessant \& Lamming 2013; Mehra \& Inman 2004). Procurement personnel traditionally tasked with procuring key resources for an organisation's production function now face new business challenges and hence a new role. Purchasing management practices of the past are now regarded as outdated activities that primarily focus on enhancing cost advantages for the business, compared to the current need for a strategic-oriented philosophy of competitiveness (Arora 2014). Therefore it is imperative that management recognises weaknesses in the procurement function and adjust to the dynamic global environment and socio-economic changes.

The main role of procurement professionals is to strategically fulfil the firm's procurement objectives in order to facilitate the firm's overall success in the industry. Handfield (2011) discusses four broad objectives of procurement within an organisation:

- supporting operational requirements

- sustaining the organisational purpose

- managing the procurement process and supplier base effectively and efficiently

- developing strong relationships with other functional groups.

\section{Supporting operational requirements}

According to Handfield (2011), this requires purchasing professionals to understand the business environment and to buy goods and services. Effective buying involves six 'rights': buying goods and services at the right price, from the right source, in the right quantity, at the right time, at the right specifications that meet users' needs and to the right internal customer. Internal customers include manufacturing, physical distribution centres, engineering and technical groups, research and development, information and technology, transportation and other services.

\section{Sustaining the organisational purpose}

Procurement professionals should develop integrated purchasing strategies that support organisational goals and 
objectives. According to Handfield (2011), these strategies involve:

- monitoring supply markets and trends in terms of material prices, supply shortages and supplier changes

- interpreting the effect of these trends on company strategies

- supporting the organisation's need for a diverse and globally competitive supply base by identifying the critical materials and services required to support company strategies in key performance areas - predominantly during new product development.

\section{Managing the procurement process and supplier base \\ In order to efficiently and effectively manage the procurement process and supplier base, there is need to identify opportunities and coordinate and manage internal operations of the firm. Managing internal operations in the most efficient and effective manner can be achieved by: \\ - providing professional training and growth opportunities for employees \\ - developing and maintaining policies and processes \\ - defining procurement strategy and structure \\ - providing procurement leadership to the organisation.}

The supply base can be enhanced through identifying new potential suppliers, developing relationships and improving and developing non-competitive existing suppliers (Handfield 2011). In support of Handfield (2011), Cha, Lee and Cha (2014) reiterate that this objective can be achieved through teamwork, collaboration and partnering, communication of purpose, ownership and accountability for sourcing processes.

\section{Developing strong relationships with other functional groups}

Organisational functions such as production and engineering, marketing, accounting, human resources and purchasing work together in designing and fulfilling the firm's goals and targets. Each function affects the performance of another function. For instance, the procurement function is responsible for spending the highest value of the firm's overall budget to meet the purchasing obligation. It submits the procurement proposal to the accounting department, who then approves the release of funds. Purchased materials must conform to the quality and specifications required by production and engineering for their manufacturing processes. Moreover, goods for resale must meet customer requirements to avoid unnecessary costs, such as those of reverse logistics, and losing customers' goodwill. This means that the procurement function must interrelate with other functions in an organisation for the overall success of the firm.

\section{Challenges facing procurement professionals in developing economies}

Personnel handling the procurement function should exhibit a high level of purchasing knowledge and skills. They should be qualified and possess the skill to examine and interpret supply and demand changes as well as handle aspects of relationships with suppliers. Lack of professionalism towards international purchasing is a risk because it may destroy the firm's relationship with other immediate stakeholders such as customers, the production department and suppliers, to mention a few. Unprofessional practices in international purchasing might result in poorly handled shipments, which may lead to unnecessary expenses, delays, anger and frustration and are a reflection of organisational incompetence and untrustworthiness (Neals 2011). Unprofessional practices can badly disrupt operations in the receiving firms as well as damage relations with its customers downstream. The stages that are involved from placing of an export order to the delivery of goods to the final consumer thus need to be professionally executed so that organisations can avoid losses which might cost the firm's very existence, such as the loss of customers, reputation and goodwill. Professionalism helps to eliminate most potential problems arising within the procurement industry.

\section{Poor corporate governance}

According to Chiboiwa, Samuel and Chipunza (2010), lack of good corporate governance leads to high labour turnover; this is spread over all sectors of the economy, thereby negatively affecting national economic growth and stability. Human resources are the most important assets of an entity. Employees expect to be rewarded according to their efforts (Laoledchai, Land \& Low 2008). Vroom's expectancy theory (Van Eerde \& Thierry 1996) holds that efforts to satisfy needs will depend on the person's perception that he or she expects the effort to be followed by a certain outcome which will bring desirable results. This theory applies to procurement organisations in the developing nations under study. Employees' expectations regarding remuneration and other benefits are not met, as indicated by poor performance and high labour turnover. At the same time, the employee compares his or her job's input-output ratio with that of others across the region and corrects any inequity. Lack of equity and justice, a clear indication of poor corporate governance, has led employees to quit their jobs (Howard \& Miller 1993).

\section{Lack of an effective and sound regulatory framework}

A complex legal and policy framework is a threat to effective procurement (Bolton 2006). It results in a lack of trust between the government and private investors such as private procuring firms (Schapper, Malta \& Gilbert 2006). This environment is characterised by non-supportive policies which act as barriers to the import and export of goods and services. This issue was raised by participants from all three countries under study and therefore requires immediate attention.

\section{Technological developments}

Technology is a dynamic process. Changes in technology are associated with high set-up costs. Financial constraints are a major drawback, especially in some developing economies, when it comes to capital projects. Modern procurement is now 
taking place online (Savage, Fransman \& Jenkins 2013; Schapper et al. 2006), yet many companies in developing economies are still lagging behind. For instance, it emerged from the workshops that most procurement functions in Namibia and Zimbabwe are still being done manually. Poor infrastructure, weak strategic alliances and reluctance to change have resulted in poor or even non-adoption of such technologies as electronic data interchange (EDI) in these two countries.

\section{Procurement costs}

Kapoor and Kansal (2003) point out that when a stock order is placed, a number of different costs can be incurred while processing and handling the order. Procurement costs include the cost of processing an order through the accounting and purchasing department, transmitting the order from the supplier, transporting the order when transportation charges are not included in the purchased goods and material handling or processing of the order at the receiving dock. Because of limited foreign currency, it may be difficult for most procurement organisations engaged in international trade to fulfil their obligation to meet all the procurement requirements stipulated in the purchasing contract. International buying involves large cash transactions and is associated with high procurement costs. Procurement professionals may be forced to reduce their order as a result of these costs. However, this decision may result in failure to meet the demand of goods and services in the receiving country (Hunja 2003; Hypo Group Alpe-Adria 2010). Thus, procurement professionals must be able to predict the level of costs associated with international buying.

\section{Discussion of findings from procurement practitioners}

Some of the issues raised by participants are summarised in Table 2. The responses were converted into descriptive statistics to convey some meaning regarding the challenges encountered and the (likely) impact on organisational operations.

The study found that the effect of one challenge within an identified sector was not the same in another sector. It emerged that lack of professionalism was the main challenge hampering effective international buying within the SMEs sector. This was supported by $50 \%$ of the respondents in the SMEs sector. This was as a result of the fact that most SMEs, especially family-owned businesses, were failing to employ highly qualified procurement personnel who understand all the necessary procedures, risks, opportunities and threats in international purchasing. In high-growth oriented and stateowned corporations, the situation was different. However, the study revealed that the profession is not being fully recognised so that only executives are engaged in supplier visits and audits.

The study also found that change in technology as a result of globalisation is another major challenge. Most small businesses were still lagging behind with regard to using modern technology such as laptops, customs software and the Internet in international purchasing. It was noted that most SMEs have limited financial reserves; hence they are failing to implement capital projects. Moreover, 20\% of the respondents indicated that a poor regulatory environment was a barrier to success in international purchasing. Duties levied on some basic goods were too much for small firms that rely on buying goods for resale from abroad. This means that those imported goods were no longer competitive on the local market, leading to unnecessary losses.

In high-growth oriented firms, ${ }^{1} 45 \%$ of the respondents noted that lack of good corporate governance was a major barrier to effective international purchasing. High-growth oriented firms were failing to reward their personnel according to performance and merit. Unfavourable remuneration packages were encouraging procurement managers to accept bribes, gifts and tips so as to sustain their families and social welfare. However, this goes against the code of ethics and purchasing principles which guide procurement staff in carrying out their duties. The study found that unfavourable working conditions were pushing most skilled personnel to leave for other countries in search of better working

1.For the purposes of this study, high-growth oriented firms refer to those firms seek ing growth in order to have significant scale because of the impact on job creation they have, for instance Debswana (Botswana); Bidvest, Namibia Breweries (Namibia); Delta Beverages, Econet (Zimbabwe). The definition also includes participants from various multinational companies that took part in the workshops.

TABLE 2: Common challenges facing procurement in developing economies.

\begin{tabular}{|c|c|c|c|c|}
\hline Industrial sector & Number of respondents & $\%$ age of respondents & Major challenges & Impact \\
\hline \multirow[t]{4}{*}{ SMES } & $20 / 40$ & $50 \%$ & Lack of professionalism & High \\
\hline & $12 / 40$ & $30 \%$ & Poor supplier service delivery time $\&$ supplier readiness & \\
\hline & $8 / 40$ & $20 \%$ & Changes in technology as a result of globalisation & \\
\hline & & & Others: corruption, poor regulatory environment & \\
\hline \multirow[t]{4}{*}{ High-growth oriented firms $\dagger$} & $12 / 26$ & $45 \%$ & Lack of good corporate governance & High \\
\hline & $14 / 26$ & $55 \%$ & $\begin{array}{l}\text { Complex regulatory environment coupled with high } \\
\text { corruption }\end{array}$ & \\
\hline & & & Varying supplier standards & \\
\hline & & & Failure to link demand to the firm's budget & \\
\hline \multirow[t]{3}{*}{ State-owned corporations } & $19 / 34$ & $50 \%$ & High level of corruption & High \\
\hline & $19 / 34$ & $50 \%$ & Poor corporate governance & \\
\hline & & & Shoddy tendering processes & \\
\hline
\end{tabular}

$\dagger$, Firms seeking growth in order to have significant scale because of the impact on job creation they have, for instance Debswana (Botswana); Bidvest, Namibia Breweries (Namibia); Delta Beverages, Econet (Zimbabwe). The definition also includes participants from various multinational companies that took part in the workshops. 
conditions. The respondents also indicated that securing import or export permits was not a one-day event and that it is associated with high costs. Most high-growth oriented firms were failing to meet the necessary requirements of state revenue collectors and regulators such as Botswana Unified Revenue Service (BURS) and Zimbabwe Revenue Authority (ZIMRA); thus, they end up paying bribes to the revenue officers to register their firms and/or have their consignment cleared through the border posts.

State-owned corporations such as Botswana Airways, Grain Marketing Board (GMB), Botswana Railways (BR), National Oil Company of Zimbabwe (NOCZIM), TransNamib Holdings Ltd (Namibian railways), Zimbabwe United Passengers Corporation (ZUPCO), to name a select few, were reported to be managed by individuals who had been instituted on political grounds and thus lacked integrity in selection. Corruption has been identified as a major obstacle in tendering, especially in these state enterprises. It was said that tenders to supply components to these enterprises were not awarded to the most suitable supplier who met the requirements outlined in the tender. Nepotism was reducing the level of professionalism, as tenders or contracts to supply goods and services were awarded to friends and relatives of those issuing the tender.

Namibian participants faced slightly different challenges, some of which were confirmed in a study on issues and challenges in Namibian logistics (Savage et al. 2013). The most important challenges mentioned include ineffective transport systems (such as limited rail network), limited harbour capacities, corruption and fraud, inadequate training on procurement, and lengthy cross-border and customs procedures. Many of the challenges procurement professionals in Namibia face are mostly logistical.

The study also found that all firms were facing several challenges and risks with regard to international procurement, including the following:

- Lack of or poor implementation of global sourcing plans.

- Lack of procurement code of ethics.

- Loss of goods as a result of fire whilst in transit.

- Theft of goods at border posts whilst waiting to be cleared.

- Loss of goods as a result of adverse weather conditions heavy rainstorms and fluctuating temperatures.

- Fluctuating demand and ever-changing customer preferences.

- Increased foreign bad debt.

It emerged from the study that procurement organisations were not doing enough to enhance sound supplier relationship as they have to source, select and appraise suppliers every time a need arises, thus increasing procurement costs.

\section{Unlocking value through professional procurement: The way forward}

In reaching solutions to the procurement challenges facing developing economies, the value that lies within the profession has to be unlocked. This should be done by building sound supplier relationships, improving the 'people' element through enhancing professionalism and corporate ethical procurement, and implementing global sourcing, amongst other issues.

\section{Building sound supplier relationships}

The importance of building relationships, partnerships and/ or collaborations in modern-day business functions cannot be over-emphasised (Saruchera et al. 2014). The procurement function is no exception. Procurement professionals need to maintain a strong relationship with their suppliers in order to be successful. Handfield (2011) outlines that supplier relationships are different from simple purchasing transactions in several ways; one of these is that there is a sense of commitment to the supplier. One concerned participant was quoted as saying:

As procurement managers, we have a tendency of only communicating with suppliers when a procurement need arises; and we don't contact our suppliers continuously in order to discuss our future needs and to determine how best to satisfy those needs by working together. (MN, male, procurement manager)

Supplier relationships are indeed critical to any profitoriented firm. The firm's choice of suppliers can affect the financial performance and profitability of the firm directly. Such choices impact on product development costs, stock levels, production schedules as well as the timely delivery of goods and services (Schapper et al. 2006). Firms have now realised that effective and efficient supplier relationship management is a critical aspect of the success of any firm given that limited supply of components can result in loss of production and increased idle time. Stronger supplier relationships generate more value to the procurement firms. To this end, Chinomona (2013) emphasises the role of information technology in enhancing supplier relationship longevity.

Supply chain managers are beginning to realise that building sound relationships with suppliers fosters loyalty and secures valuable support that goes beyond the terms and conditions of an order or the contents of a contract. Supply chain managers need to create programmes that aim to enhance the relationship between the organisation and the supplier. By engaging suppliers in a supplier relationship management (SRM) programme that seeks to develop the relationship beyond the purely transactional, companies may realise true competitive advantage in their supply chains. SRM programmes offer a broad range of tools to manage all aspects of the firm's purchasing and relationships with suppliers, vendors and other trading partners (Cha et al. 2014; Neals 2011). A well initiated and implemented SRM programme allows the organisation to manage and reduce costs, evaluate supplier performance, compare vendor prices, improve sourcing strategy, improve communication with suppliers, monitor and manage spending throughout the whole firm, and manage risks in international purchasing (Kordestani, Amini \& Salehi-Sangari 2015). 


\section{Global sourcing}

In this era of globalisation, when almost everything is done electronically, global sourcing could be a lasting solution. In fact, global procurement has been receiving increased managerial attention from both manufacturing and service firms especially since the twentieth century (Kotabe \& Murray 2004). Although global procurement is 'not a simple or easy solution to a company's sourcing needs' (Rajagopal \& Bernard 1994:4), it is of importance to note, as prescribed by Gocke (2008), that:

... if you need to set up a global sourcing office somewhere, it's more entrepreneurial groundwork, so to speak. And the people there need to be much more like entrepreneurs. They need to improvise. They need to bridge their home organisations - their headquarters - with their local supplier markets. So the intercultural management skills are regarded as even more important than that of a domestic purchasing manager... (p. 1)

If handled well, global sourcing ensures that the organisation shifts its focus to low-cost producers from the global market in its efforts to manage tight financial budgets (Kakabadse $\&$ Kakabadse 2000). Thus it results in cost savings (Schiele, Horn \& Vos 2011), enhanced innovativeness, enhanced risk management (Christopher et al. 2011) as well as international market exposure (Arora 2014), amongst many other benefits.

\section{Corporate ethical procurement}

Increasingly, organisations are required to operate within strict guidelines. This has been so especially in terms of their SCM, through a call for improvement in adhering to ethical principles and driving out any potential malpractices (Chartered Institute of Purchasing and Supply [CIPS] 2014). It is important that organisations and procurement professionals are affiliated to their relevant professional bodies and uphold that body's values. For instance, the Chartered Institutes of Purchasing and Supply (CIPS 2014) has identified a way to uphold integrity, commitment and responsibility that entails developing a code of procurement ethics, comparing the code with that of the international professional procurement body (CIPS) and educating all relevant staff on ethical procurement.

A study by Trent and Kolchin (1999) focused on how organisations are improving the purchasing process by reducing the time and effort associated with obtaining lowervalue goods and services. The study identified the methods or approaches that organisations need to emphasise over the next several years to improve the low-value purchasing process. These include electronic purchasing commerce through the Internet, i.e. using the Internet to conduct purchasing business in form of transmitting purchase orders to suppliers, following up on the status of orders, submitting requests for quotes to suppliers, placing orders with suppliers, making electronic funds transfer payments and establishing electronic data interchange capability (Monczka et al. 2008). Organisations need to develop a procurement code of ethics that can be benchmarked against international standards. All staff in charge of sourcing, supplier selection and related activities should be sensitised to this code and be aware of the implications of unethical dealings. This could help address the challenges of lack of procurement code of ethics.

\section{Conclusions and recommendations}

Current market dynamics are changing constantly. New global markets are posing new procurement challenges that 'change constantly, causing stressful competitive environments' (De Mariz, Ménard \& Abeillé 2014:56). Businesses can no longer depend upon previously established purchasing practices. It has been suggested that 'adopting smart supply-side practices can provide a business with distinct competencies in order to achieve strategic advantage' (D'Avanzo, Vonlewinski \& Vanwassenhove 2003:42). For that reason, businesses have to review their procurement-related policies and practices in view of competitive strategy variables, thus presenting procurement professionals with a new role in an effort to strengthen firms' areas of commercial strength. As the global procurement environment is evolving dramatically, procurement professionals will be expected to possess marketing skills, work on market improvements and proactively respond to such changes, but 'with an eye on their organisation's vision' (Roberts 2002:2).

The study has established that lack of good corporate governance is still the main challenge in procurement organisations in developing economies such as Zimbabwe and Namibia. Lack of professionalism by some individuals in international purchasing has destroyed affected firms' reputation as a result of loss of goodwill, loss of customers, rejects, poor products and penalties.

The study recommends that there should be collaborative research amongst universities and the entire business community with regard to promoting professionalism amongst procurement personnel in order to promote effective international purchasing. Such collaborations could go a long way in prescribing well-informed solutions to practical challenges facing the procurement profession, through a combination of academic and industrial practitioner views.

Organisations should be prepared to spend on training their procurement personnel so as to equip them with necessary technical skills in and knowledge of international purchasing. SMEs such as family-owned businesses should outsource managerial personnel to realise the objectives of the business. This will avoid conflict of interests between employed family members and the business.

Procurement organisations should devise suitable strategies for managing risks in international purchasing. One possible strategy is to have an insurance policy to provide cover in times of uncertainty. Procurement organisations should make sure that all procurement professionals have read and understood all the components of the International Code of Ethics and Purchasing Practices (CIPS 2014) and 
signed a copy to show that the content has been understood. Alternatively, firms can develop their own procurement code which should be benchmarked against international procurement practices and/or codes. Any serious breach of these regulations should result in legal action and dismissal from the procurement profession. The code should be fairly applied to all individuals regardless of political affiliation and social status.

Developing suppliers is essential for effective international purchasing. This study recommends that procurement organisations should also channel their effort and part of their resources into developing their suppliers with regard to technical processes, raw materials and finished goods, quality improvement and better ways of material handling and storage. Procurement professionals need to build a relationship with their suppliers and avoid a situation in which they only contact suppliers when there is a need within the organisation. The study also supports the view of Kordestani et al. (2015) that buyer-supplier relations should be environmentally and socially responsible.

The study further recommends that procurement professionals research better ways of building strong supplier relationships, which can be easily adopted by most procurement firms. Procurement professionals should remain with suppliers who are responsive and competitive or otherwise identify new suppliers with potential for excellent performance.

\section{Acknowledgements Competing interests}

The authors declare that they have no financial or personal relationships which may have inappropriately influenced them in writing this article.

\section{Authors' contributions}

Both authors were equally involved in the running of a series of procurement workshops in Botswana, Namibia and Zimbabwe, from which the majority of the article's findings were obtained. Both authors discussed the idea to write a paper based on the workshops. M.T. (Chinhoyi University of Technology) came up with an initial draft of the paper after which F.S. (Chinhoyi University of Technology) revised the paper structure and reframed especially the methodology, findings and conclusions sections. Both authors discussed the revised versions and agreed on further adjustments, after which F.S. finalised the manuscript.

\section{References}

Al-Mudimigh, A.S., Zairi, M. \& Ahmed, A.M.M., 2004, 'Extending the concep of supply chain: The effective management of value chains', International Journal of Production Economics 87(3), 309-320. http://dx.doi.org/10.1016/j. ijpe.2003.08.004

Anthon, S., Bogetoft, P. \& Thorsen, B.J., 2007, 'Socially optimal procurement with tight budgets and rationing', Journal of Public Economics 91(7), 1625-1642. http:// dx.doi.org/10.1016/j.jpubeco.2007.02.011

Arora, A., 2014, 'Sustainability strategies in supply chain management', PhD dissertation, Department of Marketing and Logistics, Georgia Southern University, viewed 12 May 2014, from http://digitalcommons.georgiasouthern.edu/etd/1063/
Bolton, P., 2006, 'Government procurement as a policy tool in South Africa', Journal of Public Procurement 6(3), 193.

Brown, S., Bessant, J. \& Lamming, R., 2013, Strategic operations management, 3rd edn., Routledge, London.

Cha, K.J., Lee, Z.K. \& Cha, J.S., 2014, 'Strategies for successful supplier relationship management (SRM) in the SI industry', Journal of Society for e-Business Studies 17(3), 105-116.

Chartered Institute of Purchasing and Supply (CIPS), 2014, Sustainable and ethical procurement, viewed 17 July 2014, from https://www.cips.org/en/Knowledge/ Procurement-topics-and-skills/Sustainability/Sustainable-and-EthicalProcurement/

Chiboiwa, M.W., Samuel, M.O. \& Chipunza, C., 2010, 'An examination of employee retention strategy in a private organisation in Zimbabwe', African Journal of Business Management 4(10), 2103-2109.

Chinomona, R., 2013, 'Information technology resource as a facilitator of suppliers' collaborative communication, network governance and relationship longevity in supply chains', Journal of Transport and Supply Chain Management 7(1), 1-10, viewed 12 May 2014, from http://dx.doi.org/10.4102/ jtscm.v7i1.83

Christopher, M., Mena, C., Khan, O. \& Yurt, O., 2011, 'Approaches to managing global sourcing risk', Supply Chain Management: An International Journal 16(2), 67-81. http://dx.doi.org/10.1108/13598541111115338

Coe, C.K., 1989, Public financial management, Englewood Cliffs, Prentice Hall.

D’Avanzo, R., Vonlewinski, H. \& Vanwassenhove, L.N., 2003, 'The link between supply chain and financial performance', Supply Chain Management Review 7(6), 40-47.

De Mariz, C.L., Ménard, C. \& Abeillé, B., 2014, Public procurement reforms in Africa: Challenges in institutions and governance, Oxford University Press, London. http://dx.doi.org/10.1093/acprof:0so/9780198714910.001.0001

Edler, J. \& Georghiou, L., 2007, 'Public procurement and innovation - Resurrecting the demand side', Research Policy 36(7), 949-963. http://dx.doi.org/10.1016/j. respol.2007.03.003

Gocke, A., 2008, Challenges facing procurement organisations, viewed 17 July 2014 from http://knowledge.wharton.upenn.edu/article/procurement-customersupplier-relationships/

Handfield, R., 2011, Role of procurement within an organization: Procurement: $A$ tutorial, Supply Chain Resource Cooperative, Poole College of Management North Carolina State University, Raleigh, viewed 14 June 2014, from http:// $\mathrm{scm}$.ncsu.edu/scm-articles/article/role-of-procurement-within-an-organizationprocurement-a-tutorial

Hanks, J., Davies, H. \& Perera, O., 2008, Sustainable public procurement in South Africa, International Institute for Sustainable Development, viewed 12 May 2014 from www.iisd.org/pdf/2008/spp_south_africa.pdf

Hines, T., 2004, Supply chain strategies: Customer driven and customer focused, Oxford University Press, London.

Howard, L.W. \& Miller, J.L., 1993, 'Fair pay for fair play: Estimating pay equity in professional baseball with data envelopment analysis', Academy of Management Journal 36(4), 882-894. http://dx.doi.org/10.2307/256763

Hunja, R.R., 2003, 'Obstacles to public procurement reform in developing countries', in S. Arrowsmith \& M. Trybus (eds.), Public procurement: The continuing revolution pp. 1-9, Kluwer Law International, Alphen aan den Rijn.

Huston, J.A., 1966, The sinews of war: Army logistics 1775-1953, vol. 2, Government Printing Office, Washington, DC.

Hypo Group Alpe-Adria, 2010, Risk management in international trade: A guide to conducting safe import and export transactions, Hypo Group, Klagenfurt, Austria.

Kakabadse, N. \& Kakabadse, A., 2000, 'Critical review-outsourcing: A paradigm shift', Journal of Management Development 19(8), 670-728. http://dx.doi.org/10.1108/ 02621710010377508

Kapoor, S.K. \& Kansal, P., 2003, Basics of distribution management: A logistics approach, PHI Learning, Delhi.

Kordestani, A., Amini, M. \& Salehi-Sangari, E., 2015, 'Environmentally and socially responsible buyer supplier relationship management', in K. Kubacki (ed.), Ideas in marketing: Finding the new and polishing the old, pp. 445-446, Springer, New York. http://dx.doi.org/10.1007/978-3-319-10951-0_166

Kotabe, M. \& Murray, J.Y., 2004, 'Global procurement of service activities by service firms', International Marketing Review 21(6), 615-633. http://dx.doi. org/10.1108/02651330410568042

Lambert, D.M. \& Pohlen, T.L., 2001, 'Supply chain metrics', International Journal of Logistics Management 12(1), 1-19. http://dx.doi.org/10.1108/0957409011 0806190

Laoledchai, Y., Land, L.P.W. \& Low, G., 2008, 'Improving the effectiveness of end-user training outcomes', ACIS 2008 Proceedings, Christchurch, New Zealand, December $02-05,2008$, p. 103

Levaggi, R., 1999, 'Optimal procurement contracts under a binding budget constraint', Public Choice 101(1-2), 23-37. http://dx.doi.org/10.1023/A:10183119 20072

McCue, C., Buffington, K.W. \& Howell, A.D., 2007, 'The fraud/red tape dilemma in public procurement', in L.A. Knight et al. (eds.), Public procurement: International cases and commentary, pp. 247-266, Routledge, Oxford.

Mehra, S. \& Inman, R.A., 2004, 'Purchasing management and business competitiveness in the coming decade', Production Planning \& Control 15(7), 710-718. http:// dx.doi.org/10.1080/09537280412331298247

Mentzer, J.T., DeWitt, W., Keebler, J.S., Soonhong, M., Nancy, W., Smith, D.C. et al., 2001, 'Supply chain management', Journal of Business Logistics 22(2), 1-25. http://dx.doi.org/10.1002/j.2158-1592.2001.tb00001.x 
Meredith, J. \& Samson, D., 2001, 'Call for papers: Special issue of Journal of Operations Management on case study and field research', Journal of Operations Management 19(1), 415-417.

Modi, S.B. \& Mabert, V.A., 2010, 'Exploring the relationship between efficient supply chain management and firm innovation: An archival search and analysis', Journa of Supply Chain Management 46(4), 81-94. http://dx.doi.org/10.1111/j.1745493X.2010.03207.x

Mol, M.J., 2003, 'Purchasing's strategic relevance', Journal of Purchasing and Supply Management 9(1), 43-50. http://dx.doi.org/10.1016/S0969-7012(02)00033-3

Monczka, R., Handfield, R., Giunipero, L. \& Patterson, J., 2008, Purchasing and supply chain management, Cengage Learning, Farmington Hills, Michigan.

Neals, 2011, Managing risks in procurement, Department of Education and Children's Services, Government of South Australia, Adelaide.

Page, H.R., 1980, Public purchasing and materials management, D.C. Heath, Lexington.

Perry, B., 2009, Enterprise operations, CIMA Publishing, London.

Rajagopal, S. \& Bernard, K.N., 1994, 'Global procurement: Motivations and strategy', Marketing Intelligence \& Planning 12(9), 4-17. http://dx.doi. org/10.1108/02634509410069074

Roberts, J.S., 2002, 'An interview with Kent Brittan: One on one', Journal of Supply Chain Management 38(3), 2-3. http://dx.doi.org/10.1111/j.1745-493X.2002.tb00130.x

Saruchera, F., Tukuta, M., Ndoda, G.R. \& Sikwila, M.N., 2014, 'Driving industry growth through academic excellence: A study on the strategic contribution of universityindustry knowledge transfer in revamping manufacturing SMEs in developin economies', Mediterranean Journal of Social Sciences 5(14), 252. http://dx.doi. org/10.5901/mjss.2014.v5n14p252

Savage, C.J., Fransman, L. \& Jenkins, A.K., 2013, 'Logistics in Namibia: Issues and challenges', Journal of Transport and Supply Chain Management 7(1), 1-8. http:// dx.doi.org/10.4102/jtscm.v7i1.86
Schapper, P.R., Malta, J.V. \& Gilbert, D.L., 2006, 'An analytical framework for the management and reform of public procurement', Journal of Public Procurement $6(1 / 2), 1$.

Schiele, H., Horn, P. \& Vos, B., 2011, 'Estimating cost-saving potential from international sourcing and other sourcing levers: Relative importance and tradeoffs', International Journal of Physical Distribution \& Logistics Management 41(3), 315-336. http://dx.doi.org/10.1108/01443570610646210

Schiele, J.J. \& McCue, C.P., 2006, 'Professional service acquisition in public sector procurement: A conceptual model of meaningful involvement', International Journal of Operations \& Production Management 26(3), 300-325. http://dx.doi. org/10.1108/09600031111123813

Stuart, I., McCutcheon, D., Handfield, R., McLachlin, R. \& Samson, D., 2002, 'Effective case research in operations management: A process perspective', Journal of Operations Management 20, 419-433. http://dx.doi.org/10.1016/S0272 6963(02)00022-0

Thai, K.V., 2001, 'Public procurement re-examined', Journal of Public Procurement $1(1), 9-50$.

Trent, R.J. \& Kolchin, M.G., 1999, Reducing the transaction costs of purchasing low-value goods and services, Center for Advanced Purchasing Studies, Tempe, Arizona.

Van Eerde, W. \& Thierry, H., 1996, 'Vroom's expectancy models and work-related criteria: A meta-analysis', Journal of Applied Psychology 81(5), 575. http://dx.doi. org/10.1037/0021-9010.81.5.575

Walters, D., 2012, 'Competition, collaboration, and creating value in the value chain', in H. Jodlbauer, J. Olhager \& R.J. Schonberger (eds.), Modelling value, pp. 3-36, Physica Verlag, Heidelberg. http://dx.doi.org/10.1007/978-3-79082747-7_1

Yin, R.K., 1994, Case study research design and methods, vol. 5, Sage, Newbury Park, California. 